\title{
Modelization of the regulation of protein synthesis following fertilization in sea urchin shows requirement of two processes: a destabilization of elF4E:4E-BP complex and a great stimulation of the 4E-BP-degradation mechanism, both rapamycin-sensitive
}

\author{
Sébastien Laurent ${ }^{1}$, Adrien Richard ${ }^{2}$, Odile Mulner-Lorillon ${ }^{3,4}$, Julia Morales ${ }^{3,4}$, Didier Flament ${ }^{1}$, \\ Virginie Glippa ${ }^{3,4}$, Jérémie Bourdon ${ }^{5}$, Pauline Gosselin ${ }^{3,4}$, Anne Siegel ${ }^{6,7}$, Patrick Cormier ${ }^{3,4}$ and \\ Robert Bellé $3,4 *$ \\ 1 Ifremer, UMR6197, Laboratoire de Microbiologie des Environnements Extrêmes, Plouzané, France \\ ${ }^{2}$ Université de Nice-Sophia Antipolis, UMR 7271, Laboratoire 13S, Sophia, Antipolis, France \\ ${ }^{3}$ Sorbonne Universités, UPMC University Paris 06, UMR 8227, Integrative Biology of Marine Models, Translation Cell Cycle and Development, Station Biologique \\ de Roscoff, Roscoff cedex, France \\ ${ }^{4}$ CNRS, UMR 8227, Integrative Biology of Marine Models, Translation Cell Cycle and Development, Station Biologique de Roscoff, Roscoff cedex, France \\ ${ }^{5}$ CNRS UMR 6241, Laboratoire LINA, Université de Nantes, Nantes, France \\ ${ }^{6}$ CNRS, IRISA-UMR 6074, Campus de Beaulieu, Rennes, France \\ 7 INRIA, Centre Rennes - Bretagne Atlantique, Symbiose, Campus de Beaulieu, Rennes, France
}

Edited by:

Thierry Tonon, CNRS-UPMC, France

Reviewed by:

Ying Xu, West Virginia University,

USA

Gary Wessel, Brown University,

USA

\section{*Correspondence}

Robert Bellé, Integrative Biology of Marine Models, Translation Cell

Cycle and Development, Sorbonne Universités, CNRS-UPMC University

Paris 06, Station Biologique, place

Georges Teissier, CS 90074,

29688 Roscoff Cedex, France

e-mail: belle@sb-roscoff.fr

Fertilization of sea urchin eggs involves an increase in protein synthesis associated with a decrease in the amount of the translation initiation inhibitor 4E-BP. A highly simple reaction model for the regulation of protein synthesis was built and was used to simulate the physiological changes in the total 4E-BP amount observed during time after fertilization. Our study evidenced that two changes occurring at fertilization are necessary to fit with experimental data. The first change was an 8-fold increase in the dissociation parameter $\left(\mathrm{k}_{\mathrm{off} 1}\right)$ of the elF4E:4E-BP complex. The second was an important 32.5-fold activation of the degradation mechanism of the protein 4E-BP. Additionally, the changes in both processes should occur in $5 \mathrm{~min}$ time interval post-fertilization. To validate the model, we checked that the kinetic of the predicted 4.2-fold increase of elF4E:elF4G complex concentration at fertilization matched the increase of protein synthesis experimentally observed after fertilization (6.6-fold, $S D=2.3, n=8$ ). The minimal model was also used to simulate changes observed after fertilization in the presence of rapamycin, a FRAP/mTOR inhibitor. The model showed that the elF4E:4E-BP complex destabilization was impacted and surprisingly, that the mechanism of 4E-BP degradation was also strongly affected, therefore suggesting that both processes are controlled by the protein kinase FRAP/mTOR.

Keywords: translational control, sea urchin embryos, mechanisms of fertilization, deterministic model, translation simulation

\section{INTRODUCTION}

Early development of the sea urchin embryo is one among the models which contribute to establish the paradigms of the mechanisms of translation, the eukaryotic universal process for protein biosynthesis (Mathews et al., 2007). Many factors are involved in all steps of translation machinery, namely initiation, elongation, and termination and have been extensively reviewed (Mathews et al., 2007). For the great majority of the mRNAs, the initiation step of translation occurs on activated mRNAs that contain a $\mathrm{m}^{7} \mathrm{GpppN}$ molecule (where $\mathrm{N}$ is any of the four nucleotides) at the $5^{\prime}$ end, also known as a cap structure, thus referred as cap-dependent translation initiation (Jackson et al., 1995). Not exhaustively, protein translation initiation begins with the binding of the eukaryotic initiation factor $4 \mathrm{E}$ (eIF4E) to the cap-structure of the mRNA. The protein eIF4E recruits a large scaffolding protein called eIF4G that interacts, among others, with eIF4A and eIF3 linking the $5^{\prime}$ end of the mRNA and the $43 \mathrm{~S}$ preinitiation complex (Gingras et al., 1999a). After scanning from the $5^{\prime}$ end to the start codon, the first amino acid is incorporated and the peptide elongation step proceeds (Jackson et al., 2010, 2012; Hinnebusch, 2011). The protein eIF4E is a major target for regulation of translation initiation (Sonenberg and Gingras, 1998). Its availability in the cells depends on the presence of 4E-BPs, eIF4E binding proteins, which compete with eIF4G for a common binding site on eIF4E (Mader et al., 1995). Thus 4E-BPs sequester eIF4E, and consequently prevent cap-dependent translation (Haghighat et al., 1995). The 4E-BPs phosphorylation status regulates their interaction with eIF4E: underphosphorylated 
4E-BPs bind to eIF4E and inhibit cap-dependent translation, whereas hyperphosphorylated forms do not (Pause et al., 1994). Most of the data available to date indicate that FRAP/mTOR (FKBP12 and Rapamycin-Associated Protein/mammalian Target Of Rapamycin) is the main kinase that phosphorylates 4E-BP (Brunn et al., 1997; Burnett et al., 1998) on four conserved residues in metazoans (Gingras et al., 1999b).

Among the experimental advantages of the sea urchin embryo model, genes encoding all factors involved in translation are present and are non-redundant; thus, while mammalian genomes contain three 4E-BP homologs, sea urchin contains an unique form (Morales et al., 2006). At fertilization, an increase in protein synthesis occurs, which is necessary for the initiation of development and for the occurrence of the first cell cycle (Epel, 1990; Cormier et al., 2003; Gilbert, 2003). The protein synthesis increase is independent of new transcription and involves cap-dependent initiation from maternal mRNAs already present in the unfertilized egg (Cormier et al., 2003). Fertilization triggers 4E-BP release from eIF4E and consequently protein synthesis translation through a rapamycin-, and thus, mTOR-sensitive pathway (Cormier et al., 2001; Salaun et al., 2003, 2004). An original mechanism of 4E-BP regulation first demonstrated in sea urchin, corresponds to the rapid disappearance of 4E-BP pool following fertilization (Salaun et al., 2003, 2004, 2005; Oulhen et al., 2007, 2009). Although fertilization is known to provoke many changes in the egg metabolism that could interfere on translation regulation (Epel, 1990; Gilbert, 2003; Parrington et al., 2007), we demonstrate here that a reduced model involving 4E-BP, eIF4E, and eIF4G is sufficient to explain the changes observed at fertilization on $4 \mathrm{E}-\mathrm{BP}$ level and on the increase of cap-dependent translation. Simulations using this minimal model suggest that both a 32.5-fold increase of the 4E-BP degradation mechanism and an 8-fold change in the dissociation constant $\left(\mathrm{k}_{\mathrm{off} 1}\right)$ of eIF4E:4E$\mathrm{BP}$ complex are required at fertilization and should occur in a 5 min time interval after fertilization. Furthermore, simulations of changes after fertilization in the presence of rapamycin show that the drug strongly affects the eIF4E:4E-BP complex stability and, unexpectedly, the $4 \mathrm{E}-\mathrm{BP}$ degradation mechanism implying that both mechanisms are controlled by the FRAP/mTOR protein kinase.

\section{MATERIALS AND METHODS PROTEIN PRODUCTION AND PURIFICATION}

The construction of the plasmid pAr encoding eIF4E1 from Mus musculus has already been described (Pyronnet et al., 1999) and the protocol to produce and purify Flag-tagged MmIF4E1 was performed as described herein. The cloning of Strongylocentrotus purpuratus $4 \mathrm{E}-\mathrm{BP}$ and the production of the recombinant Histagged Sp4E-BP protein was performed as described in Gosselin et al. (2011). Briefly, recombinant Sp4E-BP was produced in BL21 (DE3) strain E.coli (Novagen) and purified on an affinity column, packed with a chelating sepharose Fast Flow Resin preloaded with $\mathrm{Ni}^{2+}$ ions (Amersham Pharmacia Biotech). A second purification step was performed on a Superdex 75 column (Amersham Pharmacia Biotech). After concentration with Amicon ${ }^{\circledR}$ Ultra-4 Centrifugal Filter Units $(10 \mathrm{kDa})$, concentration of the purified proteins was estimated with a Nanodrop ND-1000.
Purification of native eIF4E was performed from Sphaerechinus granularis egg extracts using $\mathrm{m}^{7} \mathrm{GTP}$ beads as described previously (Oulhen et al., 2010). After washing, beads were suspended in Laemmli loading buffer. The amount of recovered $\mathrm{SgIF} 4 \mathrm{E}$ was determined after resolution on SDSPAGE electrophoresis and revelation by Coomassie blue staining. Quantification was performed by comparison with a range of BSA concentrations migrated on the same gel. The bands were quantified using the ImageJ 1.43j program (Wayne Rasband, National Institutes of Health, USA) after digitization of the stained gel.

\section{PREPARATION OF GAMETES AND FERTILIZATION}

Sphaerechinus granularis sea urchins collected in the Brest area (France) were maintained in running seawater. Spawning of gametes, fertilization, and cell culture were as described (Oulhen et al., 2010). When indicated, $20 \mu \mathrm{M}$ rapamycin (LC laboratories) from a $20 \mathrm{mM}$ stock solution in ethanol was added to the eggs $20 \mathrm{~min}$ before fertilization. Cleavage was scored under a light microscope. Each experiment used gametes from a single female exhibiting greater than $90 \%$ fertilization.

\section{QUANTIFICATION OF 4E-BP AND EIF4E IN SEA URCHIN EGGS}

To quantify eIF4E and 4E-BP in the sea urchin unfertilized eggs, total crude protein extracts were prepared by direct dissolution of $20 \mu \mathrm{l}$ egg pellet (corresponding to 12,000 eggs) with $150 \mu \mathrm{l}$ of SDS-Fix buffer as described (Belle et al., 2011). A range of different extract volumes was submitted to SDS-PAGE and Westernblotted together with known amounts of purified $S g I F 4 \mathrm{E}$ or recombinant $S p 4 \mathrm{E}-\mathrm{BP}$ as prepared above. Proteins in the different samples were immuno-revealed using mouse monoclonal antibody directed against eIF4E from rabbit (BD transduction laboratories, Lexington, $\mathrm{KY}$ ) or rabbit polyclonal antibodies directed against human 4E-BP2 (Rousseau et al., 1996), a generous gift from Nahum Sonenberg (McGill University, Montreal, Quebec, Canada). The antigen-antibody complex was measured by chemiluminescence using horseradish peroxydase-coupled secondary antibodies according to the manufacturer's instructions (ECL or ECL+, GE Healthcare Life Sciences). Quantification of the bands was done using the ImageJ $1.43 \mathrm{j}$ program. Measurement has been performed on extracts from eggs of 9 different females for eIF4E and 4 females for $4 \mathrm{E}-\mathrm{BP}$. Protein concentrations were calculated considering an egg volume of $0.3 \mathrm{nl}$ (diameter $80 \mu \mathrm{m}$ ).

\section{DETERMINATION OF PROTEIN SYNTHESIS IN VIVO}

Unfertilized eggs (5\% suspension in sea water) were incubated in the presence of $\left[{ }^{35} \mathrm{~S}\right]$ - L- methionine during $1 \mathrm{~h}$ at the final concentration of $10 \mu \mathrm{Ci} / \mathrm{ml}$. When indicated, $20 \mu \mathrm{M}$ rapamycin was added to the incubation mixture $20 \mathrm{~min}$ prior to fertilization. Eggs were then harvested by centrifugation, rinsed three times, re-suspended in Millipore-filtered sea water in the presence or absence of rapamycin and fertilized. At different times, batches $(500 \mu \mathrm{l})$ of the embryo suspension were taken; the cells were pelleted and frozen in liquid nitrogen. Soluble protein extracts were prepared as described in Oulhen et al. (2010). $\left[{ }^{35} \mathrm{~S}\right]$ - L-methionine incorporation into proteins was measured on duplicate aliquots of the extracts after $10 \%$ TCA precipitation on Whatman $3 \mathrm{M}$ filters and counting in a scintillation counter in the presence of Optiphase Supermix scintillation liquid. 


\section{MEASUREMENT OF 4E-BP LEVEL AFTER FERTILIZATION}

At different times, following fertilization, $20 \mu \mathrm{l}$ pelleted embryos were dissolved in $150 \mu \mathrm{l}$ of SDS-Fix buffer to prepare total crude protein extracts as above. Proteins were separated on SDS-PAGE and $4 \mathrm{E}-\mathrm{BP}$ was analyzed by immunoblotting using the rabbit polyclonal antibodies directed against human 4E-BP (see above). The antigen-antibody complex was revealed by chemoluminescence, the signal was digitalized and quantified using the ImageJ $1.43 \mathrm{j}$ software. Densitometric analysis gave relative numerical values, which were used to calculate percentages of 4E-BP present in embryos considering as a reference (i.e., 100\%) the quantity of total 4E-BP in unfertilized eggs. When necessary, percents were converted into absolute concentrations based on values for 4E-BP calculated as described above.

\section{SURFACE PLASMON RESONANCE (SPR) DATA ACQUISITION}

Data were acquired with Reichert SR7000DC spectrometer instrument (Buffalo, USA). Running buffer was HEPES $50 \mathrm{mM}$ $\mathrm{pH} 7.7 \mathrm{KCl} 150 \mathrm{mM}$ 0.5\% Igepal and flow rate was $25 \mu \mathrm{L} . \mathrm{min}^{-1}$. $60 \mu \mathrm{RIU}$ of Sp4E-BP was immobilized on a mixed SAM $\left(1 \mathrm{C}_{11^{-}}\right.$ $\left.(\mathrm{OEG})_{6}-\mathrm{COOH}: 10 \mathrm{C}_{11}-(\mathrm{OEG})_{3}-\mathrm{OH}\right)$ (Buffalo, USA) via classical amine coupling chemistry. For interaction experiment, concentration of Flag-MmIF4E1:m ${ }^{7}$ GTP was assayed by spectrophotometry and stock solution was centrifuged before use. Then a concentration range from $4.37 \mu \mathrm{M}$ to $53.9 \mathrm{nM}$ of Flag$M m I F 4 E 1: m^{7} \mathrm{GTP}$ (3-fold dilution series) was injected on the $S p 4 \mathrm{E}-\mathrm{BP}$ chip at $25^{\circ} \mathrm{C}$. Following each Flag-MmIF4E1:m ${ }^{7} \mathrm{GTP}$ injection, the chip was regenerated with $30 \mathrm{~s}$ of $10 \mathrm{mM} \mathrm{NaOH}$. Each curve displayed was double referenced with a set of 6 blank buffer injections. Data were then fitted using a global analysis method with Scrubber 2.0a software (Biologic Software, Australia). Fitting errors are reported for each kinetic constant.

\section{RESULTS}

\section{THE MINIMAL MODEL ELABORATION}

A model for cap-dependent translation initiation in sea urchin has been proposed (Belle et al., 2010) based on the systemic environment of BIOCHAM software (Calzone et al., 2006). The Biocham model contains too many reactions and undetermined parameters to allow quantitative simulations of dynamic changes occurring at fertilization. We therefore investigated the strategy of extracting a minimal core model. The model was constructed with the following reactions: (R1) the reversible association between eIF4E and 4E-BP, (R2) the reversible association of eIF4E to eIF4G, (R3) the irreversible production of protein by the initiation complex containing associated eIF4E:eIF4G, (R4) the synthesis of $4 \mathrm{E}-\mathrm{BP}$ by the initiation complex containing associated eIF4E:eIF4G and (R5) the degradation of free 4E-BP.

(R1) eIF4E + 4E-BP <-> eIF4E:4E-BP $\left(\mathrm{k}_{\mathrm{on} 1} / \mathrm{k}_{\mathrm{off} 1}=1 / \mathrm{KD}_{1}\right)$

(R2) eIF4E + eIF4G <-> eIF4E:eIF4G $\left(\mathrm{k}_{\mathrm{on} 2} / \mathrm{k}_{\mathrm{off} 2}=1 / \mathrm{KD}_{2}\right)$

(R3) eIF4E:eIF4G -> Protein + eIF4E:eIF4G ( $\left.\mathrm{k}_{\text {catProtein }}\right)$

(R4) eIF4E:eIF4G -> 4E-BP + eIF4E:eIF4G ( $\left.\mathrm{k}_{\text {cat } 4 \mathrm{E}-\mathrm{BP}}\right)$

(R5) $4 \mathrm{E}-\mathrm{BP}->0\left(\mathrm{k}_{\text {lys } 4 \mathrm{E}-\mathrm{BP}}\right)$

In this model, eIF4E is considered to be always associated to mRNAs since its affinity for the cap structure and the stability of the eIF4E: cap mRNA complex were demonstrated to be very high in other species (Sonenberg and Gingras, 1998). Global protein production is assumed to be proportional to the amount of eIF4E:eIF4G complex (R4). The total amounts of eIF4E and eIF4G were shown to remain constant after fertilization in sea urchin (Oulhen et al., 2007).

The differential equations resulting from the model using the law of mass action are as follow:

(1) $\mathrm{d}[\mathrm{eIF} 4 \mathrm{E}] / \mathrm{dt}=\mathrm{k}_{\mathrm{off} 1}[\mathrm{eIF} 4 \mathrm{E}: 4 \mathrm{E}-\mathrm{BP}]+\mathrm{k}_{\text {off2 }}[\mathrm{eIF} 4 \mathrm{E}: \mathrm{eIF} 4 \mathrm{G}]-$ $\mathrm{k}_{\mathrm{on} 1}[\mathrm{eIF} 4 \mathrm{E}][4 \mathrm{E}-\mathrm{BP}]-\mathrm{k}_{\mathrm{on} 2}[\mathrm{eIF} 4 \mathrm{E}][\mathrm{eIF} 4 \mathrm{G}]$

(2) $\mathrm{d}[4 \mathrm{E}-\mathrm{BP}] / \mathrm{dt}=\mathrm{k}_{\text {off } 1}[\mathrm{eIF} 4 \mathrm{E}: 4 \mathrm{E}-\mathrm{BP}]+\mathrm{k}_{\text {cat } 4 \mathrm{E}-\mathrm{BP}}[\mathrm{eIF} 4 \mathrm{E}: \mathrm{eIF} 4 \mathrm{G}]$ $-\mathrm{k}_{\text {lysis4E-BP }}[4 \mathrm{E}-\mathrm{BP}]-\mathrm{k}_{\text {on1 }}[\mathrm{eIF} 4 \mathrm{E}][4 \mathrm{E}-\mathrm{BP}]$

(3) $\mathrm{d}[\mathrm{eIF} 4 \mathrm{G}] / \mathrm{dt}=\mathrm{k}_{\mathrm{off} 2}[\mathrm{eIF} 4 \mathrm{E}: \mathrm{eIF} 4 \mathrm{G}]-\mathrm{k}_{\mathrm{on} 2}[\mathrm{eIF} 4 \mathrm{E}][\mathrm{eIF} 4 \mathrm{G}]$

(4) $\mathrm{d}[\mathrm{eIF} 4 \mathrm{E}: 4 \mathrm{E}-\mathrm{BP}] / \mathrm{dt}=\mathrm{k}_{\mathrm{on} 1}[\mathrm{eIF} 4 \mathrm{E}][4 \mathrm{E}-\mathrm{BP}]-\mathrm{k}_{\mathrm{off} 1}[\mathrm{eIF} 4 \mathrm{E}: 4 \mathrm{E}-$ $\mathrm{BP}]$

(5) $\mathrm{d}[\mathrm{eIF} 4 \mathrm{E}: \mathrm{eIF} 4 \mathrm{G}] / \mathrm{dt}=\mathrm{k}_{\mathrm{on} 2}[\mathrm{eIF} 4 \mathrm{E}][\mathrm{eIF} 4 \mathrm{G}] \quad-$ $\mathrm{k}_{\mathrm{off} 2}[\mathrm{eIF} 4 \mathrm{E}: \mathrm{eIF} 4 \mathrm{G}]$

(6) $\mathrm{d}[$ Protein $] / \mathrm{dt}=\mathrm{k}_{\text {catProtein }}[\mathrm{eIF} 4 \mathrm{E}: \mathrm{eIF} 4 \mathrm{G}]$

\section{PARAMETER DETERMINATION IN UNFERTILIZED EGGS}

The relevance of the core model in unfertilized eggs was studied by combining experimental data acquisition and learning procedure of unknown parameters. Initial total concentrations of $4 \mathrm{E}-\mathrm{BP}$, eIF4E, and eIF4G as well as kinetic parameters of the association of eIF4E:4E-BP and eIF4G:eIF4E complexes had to be experimentally determined and were further used to fit parameters for 4E-BP synthesis and degradation.

\section{Concentrations of the translation factors}

The concentrations of 4E-BP and eIF4E in unfertilized eggs were determined by immunoblotting and densitometric quantification as indicated in the Materials and Methods section. The total concentration of 4E-BP and eIF4E were respectively 3.67 $\mu \mathrm{M}(S D=$ $0.83, n=4)$, and $2.15 \mu \mathrm{M}(S D=0.29, n=6)$ thus indicating an excess of total 4E-BP over total eIF4E. The concentration of eIF4G could not be determined using the procedure described for $4 \mathrm{E}-\mathrm{BP}$ and eIF4E for two reasons: first, sea urchin eIF4G was present under complex post-translational modified forms (Oulhen et al., 2007) and it was therefore not clear which bands could be ascribed to eIF4G, and second, no significant and measurable amounts of endogenous nor recombinant protein had been obtained. However, it was previously demonstrated that after fertilization a rapid exchange of 4E-BP for eIF4G occurred on eIF4E with a stoichiometric behavior (Oulhen et al., 2007). Therefore, simulations were performed using a minimal eIF4G concentration equivalent to eIF4E concentration $2.15 \mu \mathrm{M}$.

\section{Determination of the kinetic parameters}

The kinetic parameters for 4E-BP: eIF4E interaction were determined by surface plasmon resonance (SPR). 4E-BP was immobilized on a chip and several concentrations of eIF4E were injected onto the chip. Figure 1 shows the overlapped sensorgrams in relative Index of Refraction Unit (RIU) and their associated theoretical fits (solid lines) resulting from global data analysis according to a one step 1:1 reaction. The kinetic parameters determined were $\mathrm{k}_{\mathrm{on} 1}=9.3 \pm 0.1 \times 10^{3} \mathrm{M}^{-1} . \mathrm{s}^{-1}$, 
$\mathrm{k}_{\mathrm{off} 1}=2.2 \pm 0.1 \times 10^{-4} \mathrm{~s}^{-1}$ and the affinity constant $K D_{1}=$ $23 \mathrm{nM}$ (Table 1), all in good concordance with published data in other species (Abiko et al., 2007; Mizuno et al., 2008). Regarding the high conservation of the binding sites among species (Joshi et al., 2005) the measured parameters likely reflect the values in the sea urchin Sphaerechinus granularis.

A direct measurement of eIF4E:eIF4G interaction could not be analyzed by surface plasmon resonance. $\mathrm{A} \mathrm{k}_{\mathrm{on} 2}=1.82 \times 10^{3}$

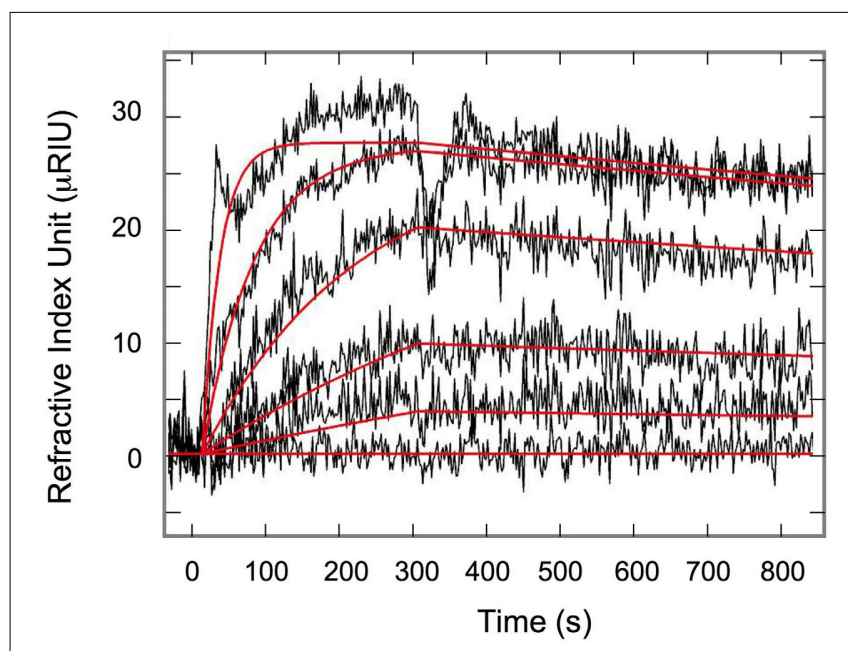

FIGURE 1 | Surface plasmon resonance Interaction of elF4E and 4E-BP. Each sensorgram, relative refractive index ( $\mu$ RIU) as a function of time, was obtained after injection of elF4E from $4.37 \mu \mathrm{M}$ to $53.9 \mathrm{nM}$ according to a three-fold dilution range. Overlapped signals were fitted using a single equilibrium kinetic isotherm (solid red lines).
$\mathrm{M}^{-1} . \mathrm{s}^{-1}$ and a $\mathrm{k}_{\mathrm{off} 2}=2.0 \times 10^{-4} \mathrm{~s}^{-1}$ for eIF4E:eIF4G interaction were used (Table 1) from published data in other species (Von Der Haar et al., 2006; Umenaga et al., 2011), resulting in determining an affinity constant for $K D_{2}=110 \mathrm{nM}$ (Table 1).

\section{Parameters for 4E-BP synthesis and degradation}

The constants for the synthesis of $4 \mathrm{E}-\mathrm{BP}\left(\mathrm{k}_{\mathrm{cat} 4 \mathrm{E}-\mathrm{BP}}\right)$ and its degradation $\left(\mathrm{k}_{\text {lys } 4 \mathrm{E}-\mathrm{BP}}\right)$ had to be determined. The degradation constant of reaction R5 was calculated from experiments consisting in the measurement of the total amount of $4 \mathrm{E}-\mathrm{BP}$ remaining after treatment of unfertilized eggs in the presence of the protein synthesis inhibitor emetine. In that condition, the disappearance of $4 \mathrm{E}-\mathrm{BP}$ depends on reactions $\mathrm{R} 1, \mathrm{R} 2$, and $\mathrm{R} 5$ since no production could occur (R4). The disappearance of total 4E-BP was simulated and the best fitting value for $\mathrm{k}_{\text {lys } 4 \mathrm{E}-\mathrm{BP}}$ was determined by optimizing the least square error to the experimental values (Figure 2). The best fit was obtained for a value of $5.9 \times 10^{-4}$ $\mathrm{s}^{-1}$ (Table 1).

Since 4E-BP remains constant in the untreated unfertilized egg, the synthesis constant, $\mathrm{k}_{\text {cat } 4 \mathrm{E}-\mathrm{BP}}(\mathrm{R} 4)$, could be calculated using reactions $\mathrm{R} 1$ to $\mathrm{R} 5$. A least-square method was used to constraint a constant value, as close as possible to $100 \%$, for the total amount of 4E-BP over time; the inferred catalytic constant for $4 \mathrm{E}-\mathrm{BP}$ synthesis was $\mathrm{k}_{\text {cat } 4 \mathrm{E}-\mathrm{BP}}=3.2 \times 10^{-3} \mathrm{~s}^{-1}$ (Table $\mathbf{1}$ ).

\section{Calculation of factor concentrations}

The unfertilized eggs are in a steady state in which the total concentrations of $4 \mathrm{E}-\mathrm{BP}$, eIF4E, and eIF4G remain constant as verified from immunoblotting experiments over the period of conservation of the eggs. Using reactions $\mathrm{R} 1$ and $\mathrm{R} 2$, the concentrations of free and complexed forms of $4 \mathrm{E}-\mathrm{BP}$, eIF4E, and eIF4G

Table 1 | Parameters of the model for translation changes at fertilization (see text for details).

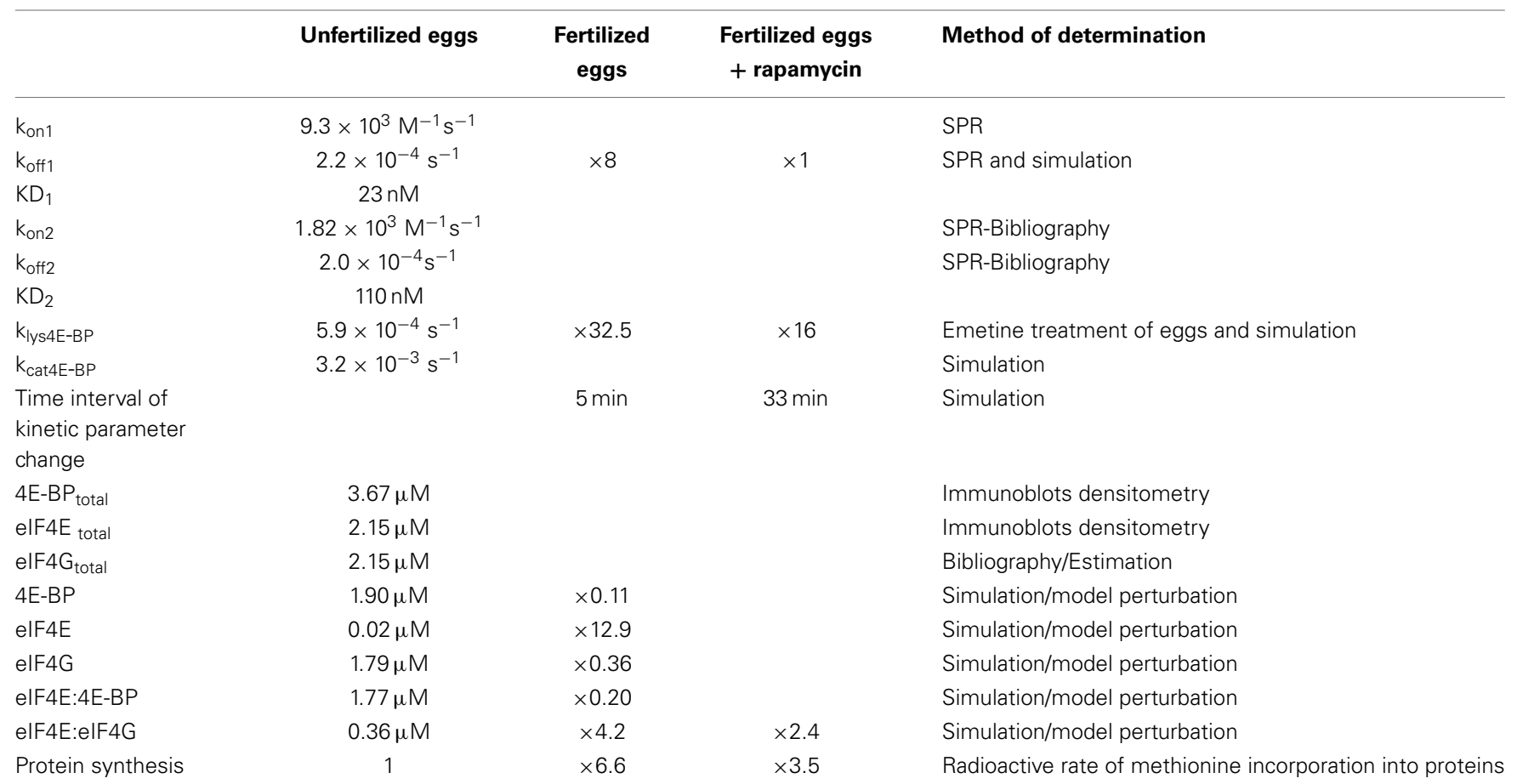




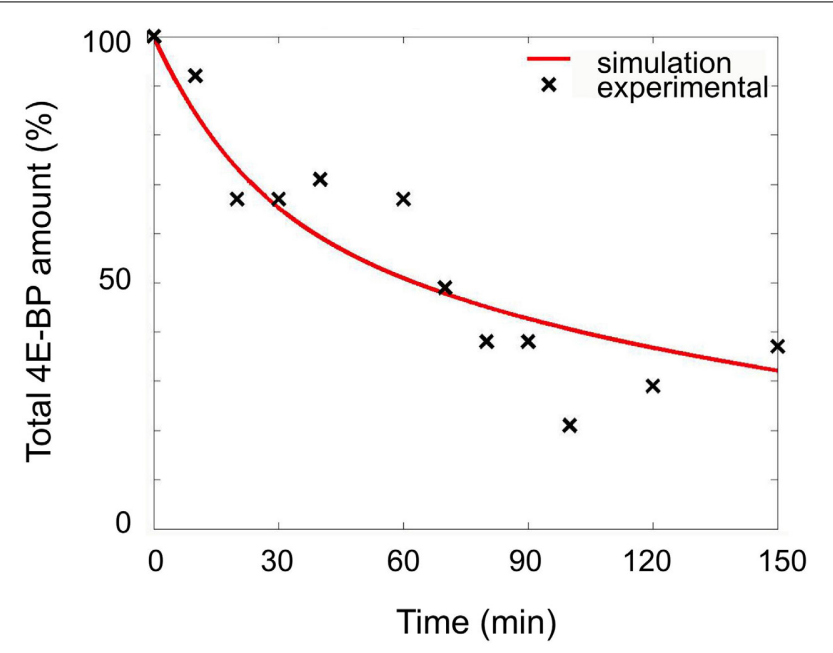

FIGURE 2 | Determination of the degradation rate of 4E-BP in unfertilized eggs. Unfertilized eggs were incubated in the presence of $100 \mu \mathrm{M}$ emetine. The amount of total 4E-BP remaining upon time was determined from immunoblotting experiments as indicated in the material and methods section. The values from 8 independent experiments are plotted as black cross. Simulation using the model (reactions R1, R2, and R5) leading to the best fit is shown as red line. The total amount of $4 \mathrm{E}-\mathrm{BP}$ is expressed as $\%$ of initial value.

could be calculated. From the differential reactions (4) and (5) of the model:

(4) $\mathrm{d}[\mathrm{eIF} 4 \mathrm{E}: 4 \mathrm{E}-\mathrm{BP}] / \mathrm{dt}=\mathrm{k}_{\text {on1 } 1}[\mathrm{eIF} 4 \mathrm{E}][4 \mathrm{E}-\mathrm{BP}]-\mathrm{k}_{\text {off } 1}[\mathrm{eIF} 4 \mathrm{E}: 4 \mathrm{E}-$ $\mathrm{BP}]=0$

(5) $\mathrm{d}[\mathrm{eIF} 4 \mathrm{E}: \mathrm{eIF} 4 \mathrm{G}] \mathrm{dt}=\mathrm{k}_{\mathrm{on} 2}[\mathrm{eIF} 4 \mathrm{E}][\mathrm{eIF} 4 \mathrm{G}]-\mathrm{k}_{\text {off2 }}[\mathrm{eIF} 4 \mathrm{E}:$ $\mathrm{eIF} 4 \mathrm{G}]=0$,

and knowing the total concentrations:

$[4 \mathrm{E}-\mathrm{BP}]_{\text {total }}=3.67 \mu \mathrm{M},[\mathrm{eIF} 4 \mathrm{E}]_{\text {total }}=[\mathrm{eIF} 4 \mathrm{G}]_{\text {total }}=2.15 \mu \mathrm{M}$, the two equations become:

$\mathrm{k}_{\text {on } 1}([\mathrm{eIF} 4 \mathrm{E}]$ total-[eIF4E:4E-BP]-[eIF4E:eIF4G] $) \quad([4 \mathrm{E}-\mathrm{BP}]$

total-[eIF4E:4E-BP]) $-\mathrm{k}_{\text {off1 }}[$ eIF4E:4E-BP] $=0$

$\mathrm{k}_{\mathrm{on} 2}([\mathrm{eIF} 4 \mathrm{E}]$ total-[eIF4E:4E-BP]-[eIF4E:eIF4G] $) \quad([\mathrm{eIF} 4 \mathrm{G}]$

total-[eIF4E:eIF4G]) $-\mathrm{k}_{\text {off } 2}$ [eIF4E:eIF4G] $=0$

from which the unknown values [eIF4E:4E-BP] and [eIF4E:eIF4G] can be calculated. From these, the free amounts of [eIF4E], [4E-BP], and [eIF4G] are deduced from the total amount minus the complexed forms

$$
\begin{aligned}
& {[\mathrm{eIF} 4 \mathrm{E}]=[\mathrm{eIF} 4 \mathrm{E}]_{\text {total }}-[\mathrm{eIF} 4 \mathrm{E}: 4 \mathrm{E}-\mathrm{BP}]-[\mathrm{eIF} 4 \mathrm{E}: \mathrm{eIF} 4 \mathrm{G}]} \\
& {[4 \mathrm{E}-\mathrm{BP}]=[4 \mathrm{E}-\mathrm{BP}]_{\text {total }}-[\mathrm{eIF} 4 \mathrm{E}: 4 \mathrm{E}-\mathrm{BP}]} \\
& {[\mathrm{eIF} 4 \mathrm{G}]=[\mathrm{eIF} 4 \mathrm{G}]_{\text {total }}-[\mathrm{eIF} 4 \mathrm{E}: \mathrm{eIF} 4 \mathrm{G}]}
\end{aligned}
$$

The calculated values are all reported in Table 1.

At that point, the parameters and steady state concentrations of all the reactions of the model are known in the unfertilized eggs (Table 1). Since protein synthesis was determined by $\left.{ }^{[35} \mathrm{S}\right]$-methionine incorporation into all translated proteins and expressed as a percentage of incorporation, the $\mathrm{k}_{\text {catProtein }}$ could not be determined. However, since in the model, the amount of protein synthesized is proportional to the concentration of [eIF4E:eIF4G], changes in [eIF4E:eIF4G] will reflect the changes in the protein synthesis rates.

\section{LEARNING PARAMETERS AND CONCENTRATIONS AFTER FERTILIZATION}

The kinetic of 4E-BP disappearance observed in vivo reveals two main features: a decrease of the total $4 \mathrm{E}-\mathrm{BP}$ protein starting from fertilization and lasting about $15 \mathrm{~min}$, followed by a stabilization of the level of the protein at $18-20 \%$ of the initial amount (Figure 3A). In parallel, the rate of protein synthesis increases and stabilizes around $30 \mathrm{~min}$ after fertilization resulting in the linear accumulation of neosynthetized proteins (Figure 3B). Therefore, fertilization corresponds to a time-dependent change from a steady state (unfertilized state) to another one (fertilized state) reached after $30 \mathrm{~min}$. With respect to the minimal model proposed, two non-exclusive changes could explain the experimental values of total 4E-BP evolution: a destabilization of eIF4E:4E-BP complex (R1) and an increase in the degradation rate $\mathrm{k}_{\text {lysis } 4 \mathrm{E}-\mathrm{BP}}$ of $4 \mathrm{E}-\mathrm{BP}$. The two hypotheses were simulated separately. Since the biochemical modifications induced by fertilization are not instantaneous (Epel, 1990; Cormier et al., 2003; Gilbert, 2003), the time necessary for the biochemical modifications to occur at fertilization through the transduction pathway was introduced in the model as a parameter time change varying linearly from the initial value of parameters in unfertilized eggs to their final value after fertilization.

A set of model simulations was first performed by perturbing the value $k_{\text {off1 }}(\mathrm{R} 1)$ ranging from its unfertilized egg value (Table 1) up to 100 times the value and by introducing a parameter time change ranging between 1 and $15 \mathrm{~min}$. For each simulation, the mean-square error between the model prediction and 4E-BP experimental data was computed. The least-worst fit (sum of square residual $=46712$ ) is shown in Figure 4A and, not surprisingly, the simulation led to a nonbiologically relevant increase in the total amount of $4 \mathrm{E}-\mathrm{BP}$. A second set of simulations was performed by perturbing the value of $\mathrm{k}_{\mathrm{lysis} 4 \mathrm{E}-\mathrm{BP}}$ ranging from its value in unfertilized eggs (Table 1) to 100 times the value while still introducing a parameter time change ranging from 1 and $15 \mathrm{~min}$. The least-worst fit (sum of square residual $=3122$ ) is shown in Figure $4 \mathrm{~B}$ and the corresponding simulation did not fully match the experimental data.

Therefore, simulations were performed by perturbing both the $\mathrm{k}_{\text {off1 }}$ value (R1), and the $\mathrm{k}_{\text {lysis4E-BP }}(\mathrm{R} 4)$ values together with a parameter time change ranging from 1 to $15 \mathrm{~min}$. Using least square method, a very good fit with the experimental data was obtained (sum of square residual $=1207$ ). The best fit was obtained when $\mathrm{k}_{\text {off }}$ increased 8-fold from the value in unfertilized eggs and $\mathrm{k}_{\text {lysis } 4 \mathrm{E}-\mathrm{BP}}$ increased 32.5 -fold with a parameter time change of $5 \mathrm{~min}$ (Figure 4C). Figure 4D shows in a color scale the least square sum of square residual values obtained in the simulations for the ranging values of $\mathrm{k}_{\text {off } 1}$ and $\mathrm{k}_{\text {lysis4E-BP. The best fit }}$ (white cross) was located in a small area related to the accuracy of the determinations. 


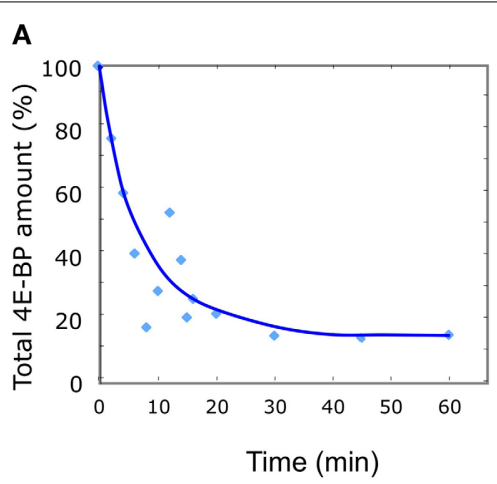

FIGURE 3 | Changes in 4E-BP total amount and protein synthesis in vivo after fertilization. (A) 4E-BP was measured by immunoblotting and densitometric quantification as described in the material and methods section. Mean values from 10 independent experiments are plotted as a function of time. The total amount of $4 \mathrm{E}-\mathrm{BP}$ is expressed as $\%$ of initial value.

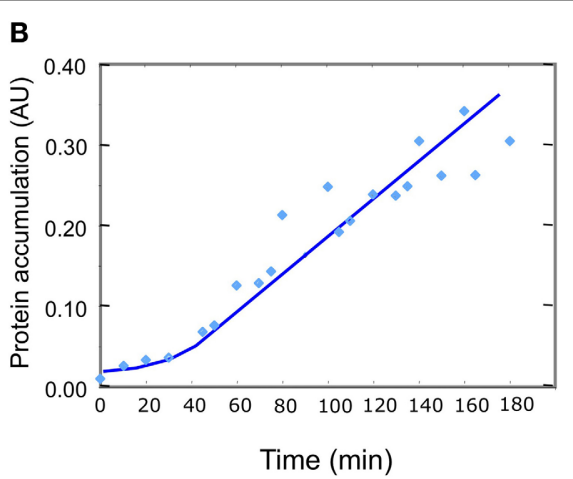

(B) Protein synthesis was determined from incorporation into proteins of ${ }^{35}$ S $]$ methionine at different times after fertilization as indicated in the Materials and Methods section. Mean values of protein accumulation from 11 independent determinations are plotted as a function of time in arbitrary unit (UA).
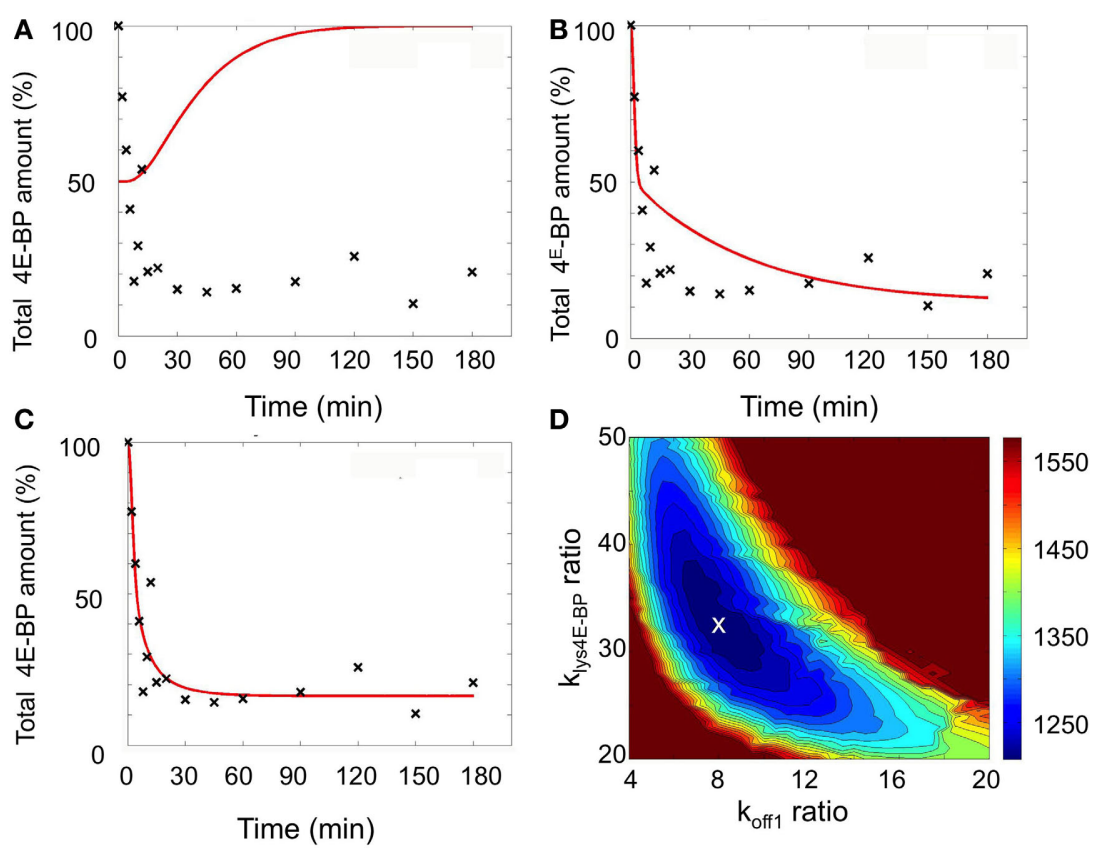

FIGURE 4 | Simulation of fertilization changes on 4E-BP using the minimal model. Best fits (red curves) compared to experimental data (black cross) are shown: (A) Ranging $k_{\text {off1 }}$ from unfertilized value (1 to 100-fold) and the parameter time change (1 to $15 \mathrm{~min}$ ). (B) Ranging klys4E-BP from unfertilized value (1-100-fold) and the parameter time change (1-15 min). (C) Changing $k_{\text {off } 1}$ and $k_{\text {lys } 4 E-B P}$ from unfertilized value (1-100-fold) and the parameter time change $(1-15 \mathrm{~min})$. (D) Color

representation of the fit according to the change of $k_{\text {off1 }}$ and $k_{\text {lys } 4 E-B P}$ when the parameter time change is fixed to $5 \mathrm{~min}$ ( $k_{\text {cat4E-BP }}$ and $k_{\text {off }} 1$ ratio are the ratio between the value reached after fertilization and the unfertilized value). The color scale on the right was associated to distance to data (sum of square residual) obtained in the simulations. The white cross corresponds to the best fit. The total amount of 4E-BP is expressed as \% of initial value.
An 8-fold increase in $\mathrm{k}_{\mathrm{off} 1}$ leads to a 8-fold increase in the $\mathrm{KD} 1 / \mathrm{KD} 2$ ratio (R1 and $\mathrm{R} 2$ ), such an increase would also be obtained through a $\mathrm{k}_{\mathrm{on} 2} 8$-fold increase or a $\mathrm{k}_{\mathrm{on} 1}$ or $\mathrm{k}_{\mathrm{off} 2} 8$-fold decrease. We therefore performed simulations with these different parameters, associated with the 32.5-fold increase in $\mathrm{k}_{\text {lysis4E-BP }}$ and a parameter time change of $5 \mathrm{~min}$. The best fits (sum of square residual) for each parameter were respectively 1207 for $\mathrm{k}_{\mathrm{off} 1}, 3692$ for $\mathrm{k}_{\mathrm{on} 2}, 3419$ for $\mathrm{k}_{\mathrm{on} 1}$ and 4214 for $\mathrm{k}_{\mathrm{off} 2}$ (Figure 5) indicating that only the 8 -fold increase in $\mathrm{k}_{\mathrm{off} 1}$ led to a good sum of square residual value.

Figure 6 shows the distance to data (sum of square residual value and SD) calculated when each parameter varied by steps from 1/32 to 32-fold compared to unfertilized values. Simulation with the best fit (sum of square residual $=1189$ ) was obtained with respectively a $\mathrm{k}_{\mathrm{off} 1} \times 8, \mathrm{k}_{\mathrm{on} 1} \times 1$, and $\mathrm{k}_{\mathrm{on} 2}$ and $\mathrm{k}_{\mathrm{off} 2} \times 1 / 27$. Regarding that this sum of square residual is not significantly 


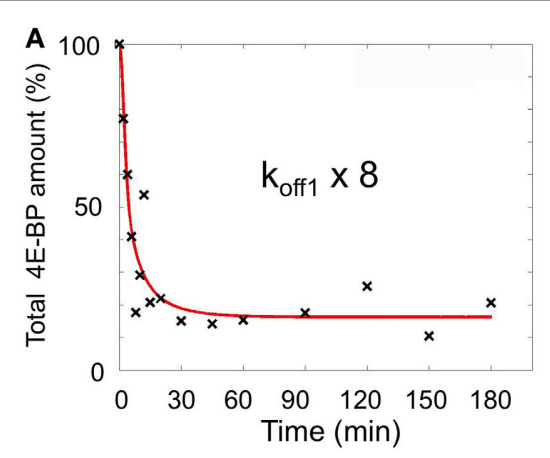

C

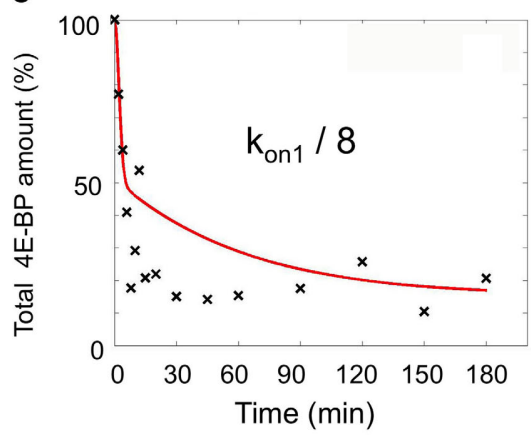

FIGURE 5 | Simulations performed varying the indicated parameters

$\left(\mathbf{k}_{\text {off1 }}, \mathbf{k}_{\text {on2 }}, \mathbf{k}_{\text {on1 }}, \mathbf{k}_{\text {off2 }}\right)$ at fertilization. $k_{\text {lys } 4 E-B P}$ was fixed as 32.5 -fold

increase compared to unfertilized eggs. Parameter time change from

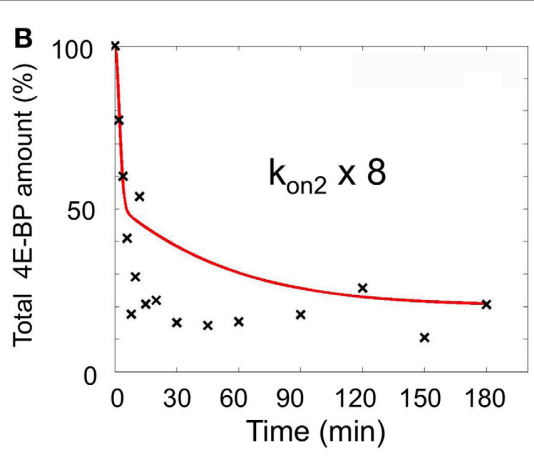

D

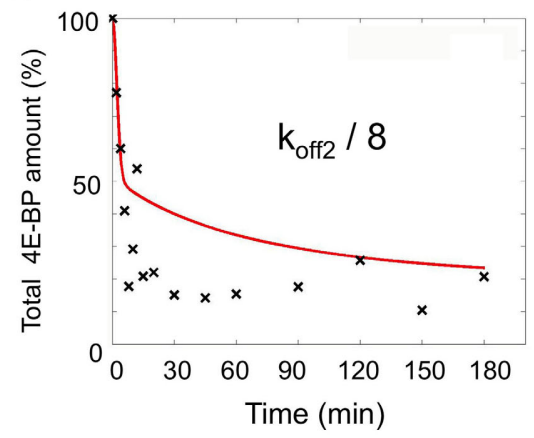

unfertilized values was set at $5 \mathrm{~min}$. The best fits (red line) for each parameter are shown (A-D) as compared to experimental data (black cross). The total amount of $4 \mathrm{E}-\mathrm{BP}$ is expressed as $\%$ of initial value. different from the distance (1207) obtained with the unique $\mathrm{k}_{\mathrm{off} 1}$ variation, the $\mathrm{k}_{\mathrm{off} 1}$ role in eIF4E:4E-BP destabilization at fertilization appears to be the most relevant.

Altogether, the model allows to conclude that destabilization of eIF4E:4E-BP complex by an 8-fold increase of its dissociation rate $\left(\mathrm{k}_{\mathrm{off} 1}\right)$ associated with a 32.5 -fold increase in the mechanism of 4E-BP degradation, both taking place in 5 min following fertilization, are necessary and sufficient to explain the observed experimental changes occurring in the total amount of $4 \mathrm{E}-\mathrm{BP}$.

Using the minimal model, the parameters determined in the unfertilized eggs and the changes predicted in the fertilized eggs (Table 1) the kinetic of concentration changes of all parameters were simulated (Figure 7). Importantly, the concentration of eIF4E:eIF4G complex increased 4.2-fold from its initial value in the unfertilized eggs, in a time interval of $30 \mathrm{~min}$. The resulting calculated increase and the protein accumulation kinetic (Figure 7, black line) were highly compatible with the in vivo protein synthesis changes after fertilization (see Figure 3B). The 4.2-fold increase in eIF4E:eIF4G complex compares favorably with the experimental 6.6-fold increase in protein synthesis measure as described in the material and methods section $(S D=$ 2.3, $n=8$ independent experiments). Although we are aware that reaction $\mathrm{R} 4$ of the model is a very highly simplified representation of the mechanism of cap-dependent translation, and that many other changes on translation factors have been reported at fertilization in sea urchin (Oulhen et al., 2007; Belle et al., 2011; Costache et al., 2012) the assumption that translation was proportional to the amount of eIF4E:eIF4G complex appeared rational in the minimal model elaboration.

\section{SIMULATION OF RAPAMYCIN EFFECT ON 4E-BP CHANGES AND PROTEIN SYNTHESIS INCREASE AT FERTILIZATION}

It has been already reported that FRAP/mTOR is involved in the protein synthesis increase following fertilization (Salaun et al., 2003, 2004, 2005; Oulhen et al., 2007). The effect of rapamycin, an inhibitor of the protein kinase FRAP/mTOR, has been analyzed in early development of sea urchin embryo. Protein synthesis measured as described in the Materials and Methods section was $53.0 \%$ ( $S D=5.1, n=8)$ of the value in control fertilized eggs. Rapamycin slowed down the decrease in the total amount 4E-BP, which stabilized at $41.7 \%(S D=5.4, n=8)$ of unfertilized value after $30 \mathrm{~min}$. This observation was rather surprising since this value is higher than the value in fertilized eggs (18\%), while protein synthesis was decreased as compared to control fertilized eggs.

The changes observed in the presence of rapamycin were modeled as a modification of the parameters of the minimal model. Simulations were performed with $\mathrm{k}_{\mathrm{off} 1}$ ranging from 1 to 8 -fold,

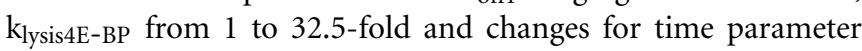
from 1 to $100 \mathrm{~min}$. A good fit was obtained for a $\mathrm{k}_{\text {off } 1} 1$-fold the

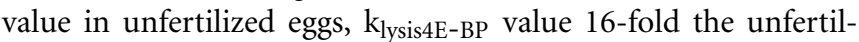
ized value and a parameter time change of $33 \mathrm{~min}$ (Figure 8 and Table 1). In these conditions, the concentration of eIF4E:eIF4G at steady state was 2.58 -fold compared to the 4.25 -fold in fertilized eggs in the absence of rapamycin. The model therefore 

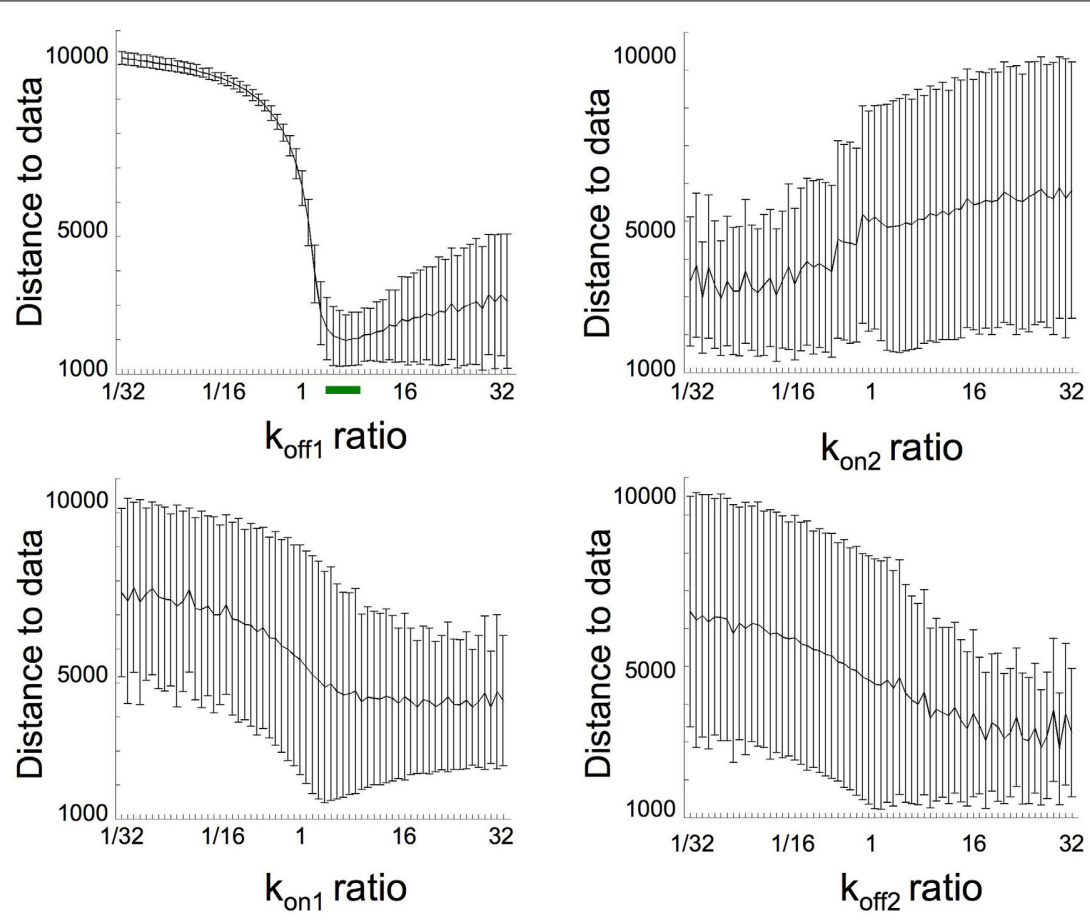

FIGURE 6 | Distance to data calculations from simulations performed varying together all of the parameters $\mathbf{k}_{\text {off1 }}, \mathbf{k}_{\mathrm{on} 2}, \mathbf{k}_{\mathrm{on} 1}, \mathbf{k}_{\mathrm{off2}}$. Each indicated parameter varied by steps from 1/32 to 32-fold compared to unfertilized values in such a way that a 8 -fold increase in $K D_{1} / K_{2}$ was maintained constant (this gives 10434 possibilities). The klys4E-BP was

fixed as 32.5-fold increase compared to unfertilized eggs and the parameter time change was fixed to $5 \mathrm{~min}$. For each possible ratio (fertilized value vs. unfertilized value), the mean and $S D$ of the distances to data were reported. Green bar corresponds to region where simulation fits well.

predicts a rapamycin-induced limited increase in protein synthesis of $53.6 \%$, in very good concordance with the experimental data value of $52.0 \%$.

Therefore the model predicted that not only $\mathrm{k}_{\mathrm{off} 1}$ increase after fertilization but also the degradation mechanism of 4E-BP is under the control of FRAP/mTOR pathway.

\section{DISCUSSION}

While the regulation of protein synthesis is a highly complex process, we show here that using a minimal model based on three main actors eIF4E, eIF4G, and 4E-BP, the changes occurring at fertilization in sea urchin could be fully simulated with adjustment of a minimum of parameters. The model postulates that fertilization triggers two events: (1) an increase in the $\mathrm{KD}_{1}$ of the eIF4E:4E-BP complex due to an 8-fold increase of the dissociation constant $\left(\mathrm{k}_{\mathrm{off} 1}\right)$ and (2) a 32.5-fold increase in the mechanism of $4 \mathrm{E}-\mathrm{BP}$ degradation $\left(\mathrm{k}_{\mathrm{lysis} 4 \mathrm{E}-\mathrm{BP}}\right)$. Therefore, the disappearance of $4 \mathrm{E}-\mathrm{BP}$ cannot result from the unique dissociation of the eIF4E:4E-BP complex. Interestingly, in mammalian cells it has been found that 4E-BP1 is degraded in eIF4E-knock-down cells (Yanagiya et al., 2012). The authors show that the noneIF4E-bound hyperphosphorylated 4E-BP1 is degraded while eIF4E-bound hypophosphorylated $4 \mathrm{E}-\mathrm{BP} 1$ is stable reinforcing our assumption in the model that only free $4 \mathrm{E}-\mathrm{BP}$ is degraded. However, it should be noted that there is no indication in this study of an activation of the mechanism of degradation itself while it is the case in sea urchin fertilization.
As expected, the model predicts that rapamycin reverses the fertilization-induced change in $\mathrm{k}_{\mathrm{off} 1}$. An attractive hypothesis would be that fertilization in sea urchin activates the kinase FRAP/mTOR that phosphorylates $4 \mathrm{E}-\mathrm{BP}$ and increases the $\mathrm{k}_{\mathrm{off} 1}$ of its association with eIF4E, resulting in a destabilization of eIF4E:4E-BP complex. A role for FRAP/mTOR protein kinase on the destabilization of eIF4E:4E-BP complex at fertilization is compatible with the observations (1) that rapamycin, a FRAP/mTOR inhibitor, inhibits protein synthesis increase in sea urchin fertilization, and inhibits the disappearance of 4E-BP upon fertilization and (2) that the $4 \mathrm{E}-\mathrm{BP}$ protein was shown to be a substrate for FRAP/mTOR in other organisms; in mammals, multiple and hierarchical phosphorylation events provoke the release of $4 \mathrm{E}-\mathrm{BP} 1$ from eIF4E, in concordance with a $\mathrm{KD}_{1}$ increase (Gingras et al., 2001). Although the relationship between FRAP/mTOR activity and the affinity of $4 \mathrm{E}-\mathrm{BP}$ for eIF4E is not established in sea urchin embryos (Oulhen et al., 2009), it has been shown that the degradation of $4 \mathrm{E}-\mathrm{BP}$ correlates with its phosphorylation (Cormier et al., 2001). Therefore, the possibility that fertilization activates FRAP/mTOR resulting in a $\mathrm{k}_{\text {off1 }}$ increase should be experimentally analyzed when the purified proteins will be available under their non-phosphorylated and phosphorylated forms.

We cannot exclude that fertilization could have also modified $\mathrm{KD}_{2}$. Since eIF4G undergoes electrophoretic changes at fertilization (Oulhen et al., 2007) it would be of interest to identify the post-translational changes occurring 


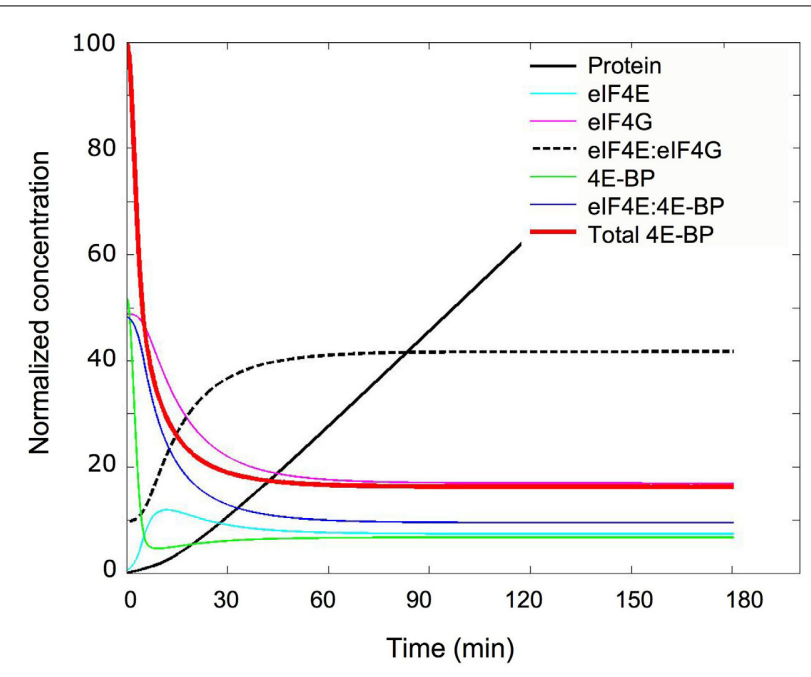

FIGURE 7 | Simulation of the concentration changes occurring at fertilization. The concentration changes of the indicated constituents were calculated and plotted vs. time after fertilization using the parameters depicted in Table 1; "elF4E," "elF4G," and "4E-BP" are the concentrations of the free forms of these proteins; "elF4E:elF4G" and "elF4E:4E-BP" correspond to the concentrations of the complexed forms; "Total 4E-BP" represents the total concentration of $4 \mathrm{E}-\mathrm{BP}$ (free and complexed). Normalization was done with $100 \%$ corresponding to the initial concentration of total $4 \mathrm{E}-\mathrm{BP}$, i.e., $3.67 \mu \mathrm{M}$ (see Table 1). The kinetic of accumulation of protein was calculated from the kinetic of elF4E:4E-BP changes and is shown in relative units (black curve).

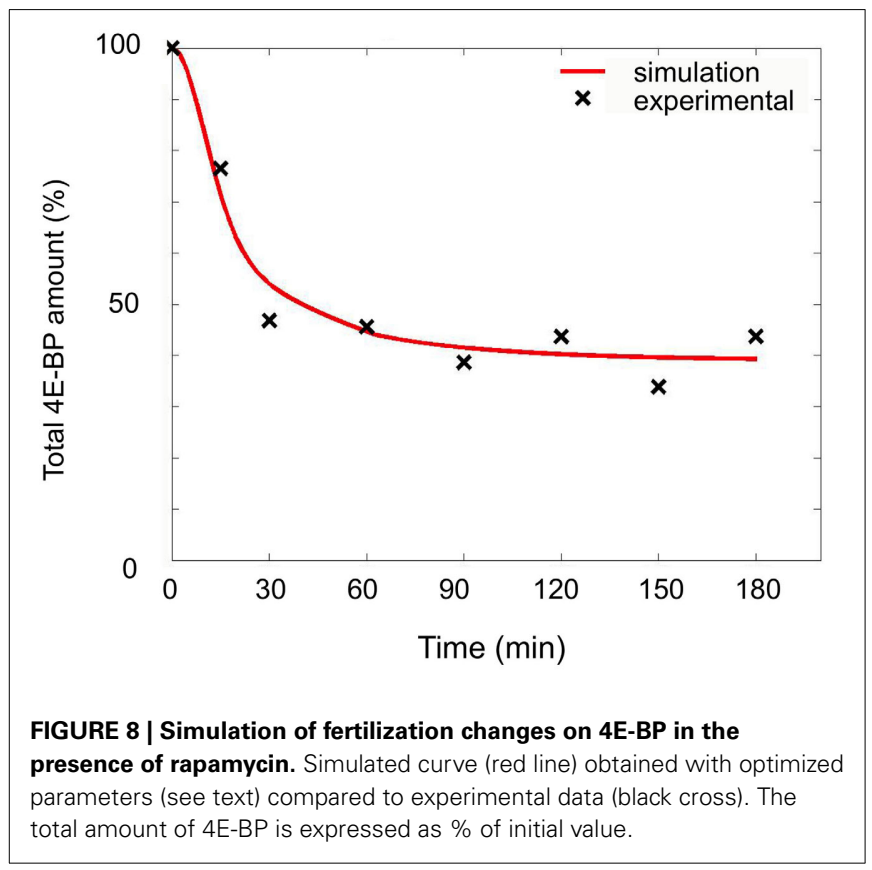

on this factor, and its consequences on eIF4E:eIF4G interaction.

Furthermore and unexpectedly, the model also predicts that the mechanism of $4 \mathrm{E}-\mathrm{BP}$ degradation was also rapamycinsensitive. Very interestingly, the degradation mechanism of 4E-BP appears to be a FRAP/mTOR target, which could also be biochemically tested when the mechanism will be identified. For now, this feature is described for the first time using sea urchin fertilization and would be of great interest to be searched in other species and other physiological regulations.

\section{AUTHOR CONTRIBUTIONS}

Sébastien Laurent and Adrien Richard equally contributed to the article as first author. Sébastien Laurent and Didier Flament designed and realized the SPR experiments. Virginie Glippa determined 4E-BP concentration in sea urchin eggs. Pauline Gosselin prepared and provided the proteins for SPR determinations. Odile Mulner-Lorillon, Julia Morales, Patrick Cormier provided the biochemical data on translation activity and protein accumulation. and Robert Bellé designed and coordinated the study. All authors contributed to the model elaboration and to the analysis of the results.

\section{ACKNOWLEDGMENTS}

This work was supported by the Ligue contre le cancer (Western France regional branch, Finistère, Côtes d'Armor, Deux Sèvres, Morbihan, and Vendée committees), the Brittany Regional Council and the Finistère Departmental Council. This work was also partially support by the French Agency for Research (ANR10_BLANC-0218 BioTempo project) and by PEPS QuantOursins CNRS grant.

\section{REFERENCES}

Abiko, F., Tomoo, K., Mizuno, A., Morino, S., Imataka, H., and Ishida, T. (2007). Binding preference of eIF4E for 4E-binding protein isoform and function of eIF4E N-terminal flexible region for interaction, studied by SPR analysis. Biochem. Biophys. Res. Commun. 355, 667-672. doi: 10.1016/j.bbrc.2007.01.198

Belle, R., Pluchon, P. F., Cormier, P., and Mulner-Lorillon, O. (2011). Identification of a new isoform of eEF2 whose phosphorylation is required for completion of cell division in sea urchin embryos. Dev. Biol. 350, 476-483. doi: 10.1016/j.ydbio.2010.12.015

Belle, R., Prigent, S., Siegel, A., and Cormier, P. (2010). Model of cap-dependent translation initiation in sea urchin: a step towards the eukaryotic translation regulation network. Mol. Reprod. Dev. 77, 257-264. doi: 10.1002/mrd.21142

Brunn, G. J., Fadden, P., Haystead, T. A., and Lawrence, J. C. Jr. (1997). The mammalian target of rapamycin phosphorylates sites having a (Ser/Thr)-Pro motif and is activated by antibodies to a region near its $\mathrm{COOH}$ terminus. J. Biol. Chem. 272, 32547-32550. doi: 10.1074/jbc.272.51.32547

Burnett, P. E., Barrow, R. K., Cohen, N. A., Snyder, S. H., and Sabatini, D. M. (1998), RAFT1 phosphorylation of the translational regulators p70 S6 kinase and 4EBP1. Proc. Natl. Acad. Sci. U.S.A. 95, 1432-1437. doi: 10.1073/pnas.95.4.1432

Calzone, L., Fages, F., and Soliman, S. (2006). BIOCHAM: an environment for modeling biological systems and formalizing experimental knowledge. Bioinformatics 22, 1805-1807. doi: 10.1093/bioinformatics/btl172

Cormier, P., Pyronnet, S., Morales, J., Mulner-Lorillon, O., Sonenberg, N., and Belle, R. (2001). eIF4E association with 4E-BP decreases rapidly following fertilization in sea urchin. Dev. Biol. 232, 275-283. doi: 10.1006/dbio.2001.0206

Cormier, P., Pyronnet, S., Salaun, P., Mulner-Lorillon, O., and Sonenberg, N. (2003). Cap-dependent translation and control of the cell cycle. Prog. Cell Cycle Res. 5, 469-475.

Costache, V., Bilotto, S., Laguerre, L., Belle, R., Cosson, B., Cormier, P., et al. (2012). Dephosphorylation of eIF2alpha is essential for protein synthesis increase and cell cycle progression after sea urchin fertilization. Dev. Biol. 365, 303-309. doi: 10.1016/j.ydbio.2012.03.002

Epel, D. (1990). The initiation of development at fertilization. Cell Differ. Dev. 29, 1-12. doi: 10.1016/0922-3371(90)90019-S

Gilbert, S. F. (2003). Developmental Biology. Sunderland, MA: Sinauer Associates. 
Gingras, A. C., Gygi, S. P., Raught, B., Polakiewicz, R. D., Abraham, R. T., Hoekstra, M. F., et al. (1999b). Regulation of 4E-BP1 phosphorylation: a novel two-step mechanism. Genes Dev. 13, 1422-1437. doi: 10.1101/gad.13.11.1422

Gingras, A. C., Raught, B., and Sonenberg, N. (1999a). eIF4 initiation factors: effectors of mRNA recruitment to ribosomes and regulators of translation. Annu. Rev. Biochem. 68, 913-963. doi: 10.1146/annurev.biochem.68.1.913

Gingras, A. C., Raught, B., and Sonenberg, N. (2001). Regulation of translation initiation by FRAP/mTOR. Genes Dev. 15, 807-826. doi: 10.1101/gad.887201

Gosselin, P., Oulhen, N., Jam, M., Ronzca, J., Cormier, P., Czjzek, M., et al. (2011). The translational repressor 4E-BP called to order by eIF4E: new structural insights by SAXS. Nucleic Acids Res. 39, 3496-3503. doi: 10.1093/nar/gkq1306

Haghighat, A., Mader, S., Pause, A., and Sonenberg, N. (1995). Repression of cap-dependent translation by $4 \mathrm{E}$-binding protein 1: competition with p220 for binding to eukaryotic initiation factor-4E. EMBO J. 14, 5701-5709.

Hinnebusch, A. G. (2011). Molecular mechanism of scanning and start codon selection in eukaryotes. Microbiol. Mol. Biol. Rev. 75, 434-467. doi: 10.1128/MMBR.00008-11

Jackson, R. J., Hellen, C. U., and Pestova, T. V. (2010). The mechanism of eukaryotic translation initiation and principles of its regulation. Nat. Rev. Mol. Cell Biol. 11, 113-127. doi: $10.1038 / \mathrm{nrm} 2838$

Jackson, R. J., Hellen, C. U., and Pestova, T. V. (2012). Termination and posttermination events in eukaryotic translation. Adv. Protein Chem. Struct. Biol. 86, 45-93. doi: 10.1016/B978-0-12-386497-0.00002-5

Jackson, R. J., Hunt, S. L., Reynolds, J. E., and Kaminski, A. (1995). Cap-dependent and cap-independent translation: operational distinctions and mechanistic interpretations. Curr. Top. Microbiol. Immunol. 203, 1-29. doi: 10.1007/978-3642-79663-0_1

Joshi, B., Lee, K., Maeder, D. L., and Jagus, R. (2005). Phylogenetic analysis of eIF4E-family members. BMC Evol. Biol. 5:48. doi: 10.1186/1471-2148-5-48

Mader, S., Lee, H., Pause, A., and Sonenberg, N. (1995). The translation initiation factor eIF-4E binds to a common motif shared by the translation factor eIF-4 gamma and the translational repressors 4E-binding proteins. Mol. Cell. Biol. 15, 4990-4997.

Mathews, M. B., Sonenberg, N., and Hershey, J. W. B. (2007). "Origins and principles of translational control," in Translational Control in Biology and Medecine, eds N. Sonenberg, J. Hershey, and M. Mathews (New York, NY: CSHL Press), $1-31$.

Mizuno, A., In, Y., Fujita, Y., Abiko, F., Miyagawa, H., Kitamura, K., et al. (2008). Importance of C-terminal flexible region of $4 \mathrm{E}$-binding protein in binding with eukaryotic initiation factor 4E. FEBS Lett. 582, 3439-3444. doi: 10.1016/j.febslet.2008.09.003

Morales, J., Mulner-Lorillon, O., Cosson, B., Morin, E., Belle, R., Bradham, C. A., et al. (2006). Translational control genes in the sea urchin genome. Dev. Biol. 300, 293-307. doi: 10.1016/j.ydbio.2006.07.036

Oulhen, N., Boulben, S., Bidinosti, M., Morales, J., Cormier, P., and Cosson, B. (2009). A variant mimicking hyperphosphorylated 4E-BP inhibits protein synthesis in a sea urchin cell-free, cap-dependent translation system. PLoS ONE 4:e5070. doi: 10.1371/journal.pone.0005070

Oulhen, N., Mulner-Lorillon, O., and Cormier, P. (2010). eIF4E-binding proteins are differentially modified after ammonia versus intracellular calcium activation of sea urchin unfertilized eggs. Mol. Reprod. Dev. 77, 83-91. doi $10.1002 / \mathrm{mrd} .21110$

Oulhen, N., Salaun, P., Cosson, B., Cormier, P., and Morales, J. (2007). After fertilization of sea urchin eggs, eIF4G is post-translationally modified and associated with the cap-binding protein eIF4E. J. Cell Sci. 120, 425-434. doi: 10.1242/jcs.03339

Parrington, J., Davis, L. C., Galione, A., and Wessel, G. (2007). Flipping the switch: how a sperm activates the egg at fertilization. Dev. Dyn. 236, 2027-2038. doi: 10.1002/dvdy. 21255
Pause, A., Belsham, G. J., Gingras, A. C., Donze, O., Lin, T. A., Lawrence, J. C., et al. (1994). Insulin-dependent stimulation of protein synthesis by phosphorylation of a regulator of $5^{\prime}$-cap function. Nature 371, 762-767. doi: 10.1038/371762a0

Pyronnet, S., Imataka, H., Gingras, A. C., Fukunaga, R., Hunter, T., and Sonenberg, N. (1999). Human eukaryotic translation initiation factor $4 \mathrm{G}$ (eIF4G) recruits mnk1 to phosphorylate eIF4E. EMBO J. 18, 270-279. doi: 10.1093/emboj/18.1.270

Rousseau, D., Gingras, A. C., Pause, A., and Sonenberg, N. (1996). The eIF4Ebinding proteins 1 and 2 are negative regulators of cell growth. Oncogene 13, 2415-2420.

Salaun, P., Boulben, S., Mulner-Lorillon, O., Belle, R., Sonenberg, N., Morales, J., et al. (2005). Embryonic-stage-dependent changes in the level of eIF4Ebinding proteins during early development of sea urchin embryos. J. Cell Sci. 118, 1385-1394. doi: 10.1242/jcs.01716

Salaun, P., Le Breton, M., Morales, J., Belle, R., Boulben, S., Mulner-Lorillon, O. et al. (2004). Signal transduction pathways that contribute to CDK1/cyclin B activation during the first mitotic division in sea urchin embryos. Exp. Cell Res. 296, 347-357. doi: 10.1016/j.yexcr.2004.02.013

Salaun, P., Pyronnet, S., Morales, J., Mulner-Lorillon, O., Belle, R., Sonenberg, N., et al. (2003). eIF4E/4E-BP dissociation and 4E-BP degradation in the first mitotic division of the sea urchin embryo. Dev. Biol. 255, 428-439. doi: 10.1016/S0012-1606(02)00099-4

Sonenberg, N., and Gingras, A. C. (1998). The mRNA $5^{\prime}$ cap-binding protein eIF4E and control of cell growth. Curr. Opin. Cell Biol. 10, 268-275. doi: 10.1016/S0955-0674(98)80150-6

Umenaga, Y., Paku, K. S., In, Y., Ishida, T., and Tomoo, K. (2011). Identification and function of the second eIF4E-binding region in N-terminal domain of eIF4G: comparison with eIF4E-binding protein. Biochem. Biophys. Res. Commun. 414, 462-467. doi: 10.1016/j.bbrc.2011.09.084

Von Der Haar, T., Oku, Y., Ptushkina, M., Moerke, N., Wagner, G., Gross, J. D., et al. (2006). Folding transitions during assembly of the eukaryotic mRNA capbinding complex. J. Mol. Biol. 356, 982-992. doi: 10.1016/j.jmb.2005.12.034

Yanagiya, A., Suyama, E., Adachi, H., Svitkin, Y. V., Aza-Blanc, P., Imataka, H., et al. (2012). Translational homeostasis via the mRNA cap-binding protein, eIF4E. Mol. Cell 46, 847-858. doi: 10.1016/j.molcel.2012.04.004

Conflict of Interest Statement: The authors declare that the research was conducted in the absence of any commercial or financial relationships that could be construed as a potential conflict of interest. The Guest Associate Editor Thierry Tonon declares that, despite being affiliated to the same institution as authors Patrick Cormier, Virginie Glippa, Julia Morales and Odile Mulner-Lorillon, the review process was handled objectively and no conflict of interest exists.

Received: 24 February 2014; accepted: 16 April 2014; published online: 06 May 2014. Citation: Laurent S, Richard A, Mulner-Lorillon O, Morales J, Flament D, Glippa V, Bourdon J, Gosselin P, Siegel A, Cormier P and Bellé R (2014) Modelization of the regulation of protein synthesis following fertilization in sea urchin shows requirement of two processes: a destabilization of eIF4E:4E-BP complex and a great stimulation of the 4E-BP-degradation mechanism, both rapamycin-sensitive. Front. Genet. 5:117. doi: 10.3389/fgene.2014.00117

This article was submitted to Systems Biology, a section of the journal Frontiers in Genetics.

Copyright (C) 2014 Laurent, Richard, Mulner-Lorillon, Morales, Flament, Glippa, Bourdon, Gosselin, Siegel, Cormier and Bellé. This is an open-access article distributed under the terms of the Creative Commons Attribution License (CC BY). The use, distribution or reproduction in other forums is permitted, provided the original author(s) or licensor are credited and that the original publication in this journal is cited, in accordance with accepted academic practice. No use, distribution or reproduction is permitted which does not comply with these terms. 